\title{
Tytuły profesorskie, habilitacje i doktoraty z zakresu edukacji wielo - i międzykulturowej uzyskane w 2017 roku w dyscyplinie pedagogika
}

\section{Tytuły profesorskie}

1. Ewa Ogrodzka-Mazur: Szkoty z polskim językiem nauczania w zróżnicowanej kulturowo Europie oraz tożsamość kulturowa postrzegana z perspektywy społeczności tych szkót (uczniów, ich rodziców i nauczycieli). Między etnicznościa a integracją. Uniwersytet im. Adama Mickiewicza w Poznaniu, Wydział Studiów Edukacyjnych.

2. Alina Szczurek-Boruta: dyptyk pedagogiczny: Doświadczenia społeczne w przygotowaniu przyszłych nauczycieli do pracy w warunkach wielokulturowości (2013). O przygotowaniu nauczycieli do pracy w warunkach wielokulturowości (2014). Uniwersytet im. Adama Mickiewicza w Poznaniu, Wydział Studiów Edukacyjnych.

\section{Habilitacje}

1. Aniela Różańska: Edukacja religijna młodzieży w warunkach pluralizmu religijnego w wybranych krajach Europy Środkowo-Wschodniej (Grupa Wyszehradzka: Polska, Czechy, Stowacja, Wegry) - studium porównawcze. Uniwersytet Mikołaja Kopernika w Toruniu, Wydział Nauk Pedagogicznych.

\section{Doktoraty}

1. Aneta Baranowska: Biograficzny wymiar migracji. Pomoc $i$ wsparcie społeczne imigrantów $w$ Polsce. Uniwersytet im. Adama Mickiewicza w Poznaniu, Wydział Studiów Edukacyjnych. Promotor: prof. dr hab. Magdalena Piorunek.

2. Olga Krasuska: Sytuacja szkolna dzieci z Kaukazu w szkołach powiatu bialskiego. Katolicki Uniwersytet Lubelski Jana Pawła II, Wydział Nauk Społecznych. Promotor: dr hab. Alina Rynio. 
3. Anna Linka: Kompetencja międzykulturowa pracowników stużb spotecznych. Uniwersytet Szczeciński, Wydział Humanistyczny. Promotor: prof. dr hab. Barbara Kromolicka.

4. Alina Stechnij: Tożsamość młodzieży jako zaniechana kwestia wychowawcza. Dolnośląska Szkoła Wyższa, Wydział Nauk Pedagogicznych. Promotor: prof. zw. dr hab. Zbigniew Kwieciński.

Opracowanie

Ewa Ogrodzka-Mazur 